\title{
PROSEPTASINE IN THE TREATMENT OF RHEUMATOID ARTHRITIS
}

BY

\author{
L. J. BARFORD \\ London
}

(RECEIVED FOR PUBLICATION OCTOBER 27, 1952)

Systematic treatment of rheumatoid arthritis with sulphonamides was instituted in Australia by Parr and Shipton (1947), and in Stockholm by Svartz (1948). Parr used principally benzylsulphanilamide ( $\mathrm{M}$ and B 125), which is marketed as Proseptasine. Svartz used an azo compound between salicylic acid and sulphapyridine, known as Salazopyrin, which has not been readily available in England. Both these observers recommended prolonged continuous treatment over months or years, and each claimed successful results: Parr in 70 per cent. of 75 cases, and Svartz in 63 per cent. of 307 cases followed up. Both reported a high relapse rate when the drug was discontinued.

The dose of azo compound used by Svartz was $6 \mathrm{~g}$. in 24 hours, reducing to $0.5 \mathrm{~g}$. two to three times a day. Patients remained on this small dose for periods of months or years. The sulphonamide content of the azo compound is approximately 60 per cent., so that the doses of sulphonamide were a little over half of those just mentioned. Parr's doses of Proseptasine ranged from $0.5 \mathrm{~g}$. three times daily to $0.25 \mathrm{~g}$. twice daily. Parr took the precaution to prescribe a vitamin B supplement throughout, and Svartz gave oral or parenteral liver preparations occasionally.

Virkkunen (1947) has also reported on a series of 38 cases in Finland, which were treated with various sulphonamides for 2 months.

\section{Present Investigations}

The technique I have used has followed that of Parr. As a vitamin B supplement I have used nine dried yeast tablets or one teaspoonful of proteolysed liver daily. The only patient in my series to whom, by an oversight, a vitamin B supplement was not given, developed a severe ulcerative stomatitis, which cleared when the drug was withheld and liver taken.

There were 59 cases in this series, mostly out-patients at the East Surrey Hospital, Redhill. They were all cases of polyarthritis of rheumatoid type. Sulphamezathine was used in a few cases instead of Proseptasine. Almost all the cases had received other forms of treatment, with indifferent success, before the Proseptasine was started.

Of the 59 cases, 49 were females and ten males. Toxic effects occurred in the early stages in five females and sulphonamide treatment was abandoned. These effects included rashes, sore eyes, headache, nausea, and dysuria. There was nearly always some nausea for the first 2 to 3 weeks of treatment. In ten other cases the documentation or follow-up was incomplete and they have been excluded from the analysis. Of the remaining 44 cases, 34 were females, and 10 males. The oldest was 74 and the youngest 28; 27 were aged 50 or over, and 17 under 50 (Table I). The duration of the disease ranged from 3 months to 25 years, and the duration of treatment with Proseptasine from 1 to 46 months. Twelve patients took Proseptasine continuously for 1 year or longer.

TABLE I

\begin{tabular}{c|c|c|c|c|c|c|c}
\hline $\begin{array}{c}\text { Cases } \\
\text { Fully } \\
\text { Treated }\end{array}$ & \multicolumn{2}{|c|}{ Sex } & \multicolumn{2}{|c|}{ Age } & \multicolumn{2}{|c|}{ Condition } \\
\hline 44 & 34 & $\mathbf{M}$ & Over 50 & Under 50 & Improved & Same or Worse \\
\hline 44 & $\frac{17}{32}$ & $\frac{12}{17}$ \\
\hline
\end{tabular}

Of twelve cases treated for more than one year eleven improved and one remained the same.

\section{Results}

Improvement in rheumatoid arthritis is very difficult to assess in physical measurements. As has been said in another place, "good health and ill are not separated by a gulf, but by a,vague line of demarcation which can shift in either direction ... chronic disease cannot be cured, it can still only be treated". These cases have been considered in terms of everyday life, such as bed-fast or not, chair-fast or not, ability to do full or part housework, ability to dress unaided, do the hair, climb stairs, walk, and attend to business, and these factors have been assessed together with degree of pain, appearance of joints, joint tenderness, and range of movement. An assessment that escapes criticism, however, is very difficult to achieve. 
TABLE II

BLOOD COUNTS AFTER ONE YEAR OR LONGER OF CONTINUOUS PROSEPTASINE THERAPY

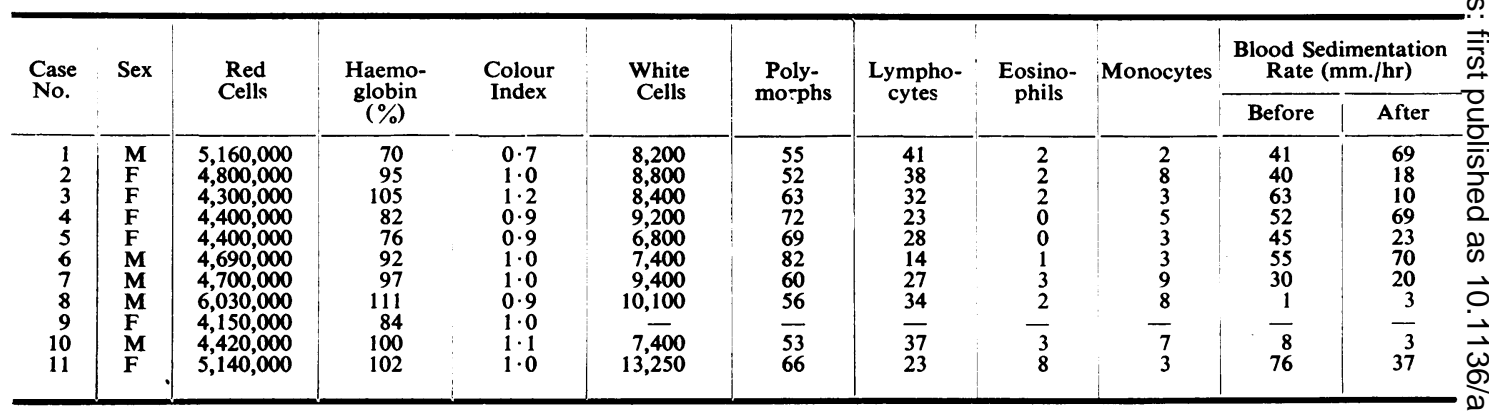

Of the 44 cases under treatment for a reasonable time (Table I), 32 improved, some remarkably so, eleven remained the same, and one deteriorated.

Of the twelve cases under treatment for a year or longer, eleven improved and one remained the same (this one had sulphamezathine instead of Proseptasine). The relapse rate, when the drug was withdrawn, was high, and relapses occurred within a few weeks. When the drug was restarted the response was the same as before.

There was no constant effect on the blood sedimentation rate. After prolonged continuous treatment the blood counts showed no gross abnormality (Table II). Clinical improvement, when it occurred, became apparent after about 4 weeks' treatment. Improvement or otherwise bore no relation to the severity of the disease as judged by the blood sedimentation rate (Table III).

\begin{tabular}{|c|c|c|c|c|c|}
\hline \multirow{3}{*}{$\begin{array}{c}\text { Blood } \\
\text { Sedi- } \\
\text { mentation } \\
\text { Rate } \\
\text { (mm./hr) }\end{array}$} & \multirow{3}{*}{$\begin{array}{l}\text { No. of } \\
\text { Cases }\end{array}$} & \multicolumn{3}{|c|}{ Condition } & \multirow{3}{*}{$\begin{array}{c}\text { No Relapse } \\
\text { on With- } \\
\text { drawal }\end{array}$} \\
\hline & & \multicolumn{2}{|c|}{ Improved } & \multirow{2}{*}{$\begin{array}{c}\text { Same } \\
\text { or } \\
\text { Worse }\end{array}$} & \\
\hline & & No. & $\%$ & & \\
\hline $\begin{array}{r}0-15 \\
16-30 \\
31-45 \\
46-60 \\
61-75 \\
76-90\end{array}$ & $\begin{array}{r}15 \\
9 \\
11 \\
6 \\
2 \\
1\end{array}$ & $\begin{array}{r}11 \\
6 \\
8 \\
4 \\
2 \\
1\end{array}$ & $\begin{array}{r}73 \\
66 \\
73 \\
66 \\
100 \\
100\end{array}$ & $\begin{array}{l}4 \\
3 \\
3 \\
2 \\
-\end{array}$ & $\begin{array}{l}\frac{3}{1} \\
\frac{1}{-}\end{array}$ \\
\hline
\end{tabular}

In Table IV the clinical results in this series are compared with those of Svartz and Parr.

\section{Discussion}

So long as the cause of rheumatoid arthritis is unknown, the infective factor remains neither proved nor disproved. Hypersensitivity, due to an abnormal defence mechanism, ranks high amongst the possibilities. The introduction of cortisone has tended to strengthen this hypothesis. Svartz was able to show

\begin{tabular}{|c|c|c|c|c|}
\hline $\begin{array}{l}\text { Author and } \\
\text { Date }\end{array}$ & Drug & $\begin{array}{l}\text { No. of } \\
\text { Cases }\end{array}$ & $\begin{array}{l}\text { Percentage } \\
\text { Improved }\end{array}$ & $\begin{array}{c}\text { Relapse } \\
\text { Rate }\end{array}$ \\
\hline $\begin{array}{l}\text { Svartz } \\
(1947)\end{array}$ & Salazopyrin & 307 & 63 & High \\
\hline $\begin{array}{l}\text { Parr and } \\
\text { Shipton (1947) }\end{array}$ & Proseptasine & 75 & 70 & High \\
\hline $\begin{array}{l}\text { Barford } \\
\text { (Present } \\
\text { Sei ies) }\end{array}$ & Proseptasine & \begin{tabular}{|cc}
49 \\
(including \\
5 & toxic)
\end{tabular} & 65 & High \\
\hline
\end{tabular}

that the azo compound was deposited in the connective tissue, and Hill, Deane, and Coons (1950), in an experiment with Friedlander bacillus poly- $\mathbb{Q}$ saccharide tagged with fluorescein, found after $\overrightarrow{\vec{P}}$ intravenous injections in mice that some of this $\frac{3}{3}$ antigen was taken up by phacytes, but that large $\underset{\partial}{\vec{\partial}}$ amounts became fixed in the synovial membrane and fibrous tissue, and that some even penetrated into cartilagenous cells. The antigen was also present on collagenous fibres throughout the body. Svartz $\bar{\sigma}$ regarded her observations as suggesting an inflam- $\frac{3}{6}$. matory as well as an allergic pathology. Hill's experi- $\delta$ ments very strongly support the allergic hypothesis.

Brown and others (1951) found that rheumatoid $\frac{}{5}$ arthritis could be influenced by some of the anti- $>$ biotics - too large a dose causing exacerbation and a을. smaller one remission. They interpreted this as N evidence supporting the basic theory of hyper-o sensitivity. They regarded the exacerbation following $N$ large doses in terms of an increased antibody- $N$ antigen reaction due to an induced release of addi- 0 tional antigen by the antibiotic. This effect could be neutralized by cortisone given at the same time.

The favourable influence of some of the sulphon- $\stackrel{\oplus}{?}$ amides on rheumatoid arthritis, and the observation 7 that relapse follows withdrawal, supports the sug-

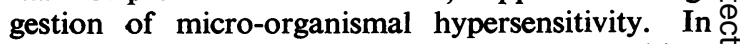
terms of this hypothesis it at once becomes evident $\stackrel{\mathbb{Q}}{\circ}$ 
that treatment could be directed towards two distinct ends:

(i) diminution of antigen-antibody activity, as with cortisone, gold, or other substances,

(ii) abolition or reduction of the amount of antigen as with certain sulphonamides and antibiotics. The two methods are complementary to each other.

No conclusion can be drawn from the small series of cases under review. Most of these patients had had some other form of treatment at the same time. On the other hand, in most of them previous treatment had been unsatisfactory. Treatment with Proseptasine is essentially a long-term treatment. Toxic effects are easily recognized and occurred in less than 10 per cent. of cases. Prolonged treatment caused no gross abnormality in the blood count. It would appear that Proseptasine may help to hold the disease in check until a remission occurs.

\section{Summary}

Forty-nine cases of rheumatoid arthritis have been treated with Proseptasine for periods ranging from one month to nearly 4 years. The improvement rate was 65 per cent., which corresponds closely with other reported series. There was no constant effect on the blood sedimentation rate. The blood picture was not adversely influenced by prolonged treatment.
I have to thank Dr. Harry Coke and Dr. L. P. B. Chamberlain for the pathological investigations.

\section{REFERENCES}

Brown, T. McP., Wichelhausen, R. H., Merchant, W. R., and Robinson, L. B. (1951). Amer. J. med. Sci. 221, 618 .

Hill, A. G. S., Deane, H. W., and Coons, A. H. (1950). J. exp. Med., 92, 35.

Parr, L. J. A., and Shipton, E. A. (1947). Med. J. Aust., 1, 323.

Svartz, N. (1948). Rheumatism, 4, 180.

Virkkunen, M. (1947). Ann. Med. intern. Fenn., 36, 198.

Proseptasine dans le traitement de l'arthrite rhumatismale RÉSUMÉ

Quarante-neuf cas d'arthrite rhumatismale furent traités par la Proseptasine pendant des périodes de un mois à presque quatre ans. Le chiffre des améliorations s'éleva à 65 pour cent, ce qui correspond étroitement aux résultats obtenus avec des séries précédentes et déjà rapportés. Il n'y eut pas d'effet constant sur la vitesse de la sédimentation globulaire. Le traitement prolongé n'influa pas défavorablement sur la formule sanguine.

Proseptasina en el tratamiento de la artritis reumatoide Sumario

Cuarenta y nueve casos de artritis reumatoide fueron tratados con Proseptasina durante períodos de un mes a cerca de cuatro años. La cifra de las mejorías elevábase a $65 \%$, lo que corresponde estrechamente a los resultados relatados de los series precedentes. No hubo efecto constante sobre la sedimentación eritrocitaria. El tratamiento prolongado no tuvo influencia desfavorable sobre la formula sanguínea. 